\title{
IfIISGUC.ORG
}

"İș, GÜC̣" ENDÜSTRi ilișKiLERI VE inSAN KAYNAKLARI DERGisi

"IS, GUC" INDUSTRIAL RELATIONS AND HUMAN RESOURCES JOURNAL

\section{Statistical Analysis of a Group to Support Decision Making Processes}

\author{
Karar Verme Süreçlerini Desteklemek Amacıyla Bir \\ Grubun İstatistiksel Analizi
}

\section{İmran ASLAN}

Erzincan Üniversitesi, İktisadi ve İdari Bilimler Fakültesi
Selahattin YAVUZ

Erzincan Üniversitesi, İktisadi ve İdari Bilimler Fakültesi

Ocak/January 2012, Cilt/Vol: 14, Sayı/Num:1, Page: 65-90 ISSN: 1303-2860, DOI: 10.4026/1303-2860.2012.195.x

Makalenin on-line kopyasına erişmek için:

http://www.isguc.org/?p=article\&id=471\&vol=14\&num=1\&year=2012

To reach the on-line copy of article:

http://www.isguc.org/?p=article\&id=471\&vol=14\&num=1\&year=2012

Makale İçin İletişim/Correspondence to: 
(C) 2000- 2012

“İşGüç" Endüstri İlişkileri ve İnsan Kaynakları Dergisi

"İşGüç" Industrial Relations and Human Resources Journal

\author{
Ocak/January 2012, Cilt/Vol: 14, Sayı/Num: 1 \\ ISSN: 1303-2860, DOI: 10.4026/1303-2860.2012.195.x
}

\section{Editör/Editor-in-Chief \\ Aşkın Keser (Uludă̆ University)}

Editör Yardimcıları/Co-Editors

K.Ahmet Sevimli (Uludağ University)

Gözde Yilmaz (Marmara University)

Uygulama/Design

Yusuf Budak (Kocaeli Universtiy)

\author{
Yayın Kurulu / Editorial Board \\ Dr. Erdem Cam (ÇASGEM) \\ Dr. Zerrin Furat (Uludă̆ University) \\ Doç. Dr. Aşkın Keser (Uludağ University) \\ Prof. Dr. Ahmet Selamoğlu (Kocaeli University) \\ Yrd. Doç. Dr. Ahmet Sevimli (Uludăg University) \\ Doç. Dr. Abdulkadir Şenkal (Kocaeli University) \\ Doç. Dr. Gözde Yilmaz (Marmara University) \\ Dr. Memet Zencirkıran (Uludă̆ University)
}

Uluslararası Danışma Kurulu / International Advisory Board Prof. Dr. Ronald Burke (York University - CA)

Assoc. Prof. Dr. Glenn Dawes (James Cook University - AU)

Prof. Dr. Jan Dul (Erasmus University - NL)

Prof. Dr. Alev Efendioğlu (University of San Francisco - USA)

Prof. Dr. Adrian Furnham (University College London - UK)

Prof. Dr. Alan Geare (University of Otago - NZ)

Prof. Dr. Ricky Griffin (TAMU-Texas AEM University - USA)

Assoc. Prof. Dr. Diana Lipinskiene (Kaunos University - LT)

Prof. Dr. George Manning (Northern Kentucky University - USA)

Prof. Dr. William L. Murray (University of San Francisco - USA)

Prof. Dr. Mustafa Özbilgin (Brunel University - UK)

Assoc. Prof. Dr. Owen Stanley (James Cook University - AU)

Prof. Dr. Işık Urla Zeytinoğlu (McMaster University - CA)

\section{Ulusal Danışma Kurulu / National Advisory Board}

Prof. Dr. Yusuf Alper (Uludağ University)

Prof. Dr. Veysel Bozkurt (İstanbul University)

Prof. Dr. Toker Dereli (Işık University)

Prof. Dr. Nihat Erdoğmuş (Şehir University)

Doç. Dr. Mustafa Kurt (Yalova University)

Prof. Dr. Ahmet Makal (Ankara University)

Prof. Dr. Süleyman Özdemir (İstanbul University)

Prof. Dr. Ahmet Selamoğlu (Kocaeli University)

Prof. Dr. Nadir Sŭ̆ur (Anadolu University)

Prof. Dr. Nursel Telman (Maltepe University)

Prof. Dr. Cavide Uyargil (İstanbul University)

Prof. Dr. Engin Yildirum (Constitutional Court of Turkey)

Doç. Dr. Arzu Wasti (Sabancı University)

Dergide yayınlanan yazılardaki görüşler ve bu konudaki sorumluluk yazarlarına aittir.

Yayınlanan eserlerde yer alan tüm içerik kaynak gösterilmeden kullanılamaz.

All the opinions written in articles are under responsibilities of the outhors.

The published contents in the articles cannot be used without being cited. 


\title{
Statistical Analysis of a Group to Support Decision Making Processes
}

\author{
Karar Verme Süreçlerini Desteklemek Amactyla Bir Grubun \\ İstatistiksel Analizi
}

\author{
İmran ASLAN \\ Erzincan Üniversitesi, İktisadi ve \\ İdari Bilimler Fakültesi
}

\author{
Selahattin YAVUZ \\ Erzincan Üniversitesi, İktisadi ve \\ İdari Bilimler Fakültesi
}

\begin{abstract}
The purpose of the survey is to determine the problems of Kipaş Group facing with point of view of the employees who have been working at top management of the group in long time. In collection of data directed to create knowledge in determination of problems of the Kipaş Group, it was benefited from survey techniques and interviews. The data were analyzed by using frequency graphs, pie charts and satisfaction analysis and combined with interviews' findings and observations. Kipaş Group has decided to change its management structure due to internal problems and external conditions since 2005 in order to establish a holding. Thus, we have carried out some surveys to gather information about the organization. In this article, the results of surveys conducted at the reorganization project of Kipas Group are presented with some important findings. 40 questions about the group were asked about 43 persons from the top management. Moreover, interviews were carried out after they filled the survey. The aims of these questions are to find how the group carries out its work and to bring out weak and strong sides of the group. These findings helped while analyzing the group. The mean, standard deviation and frequency of each question were found and presented via graphics. The satisfaction analysis was carried out to learn the common opinion about each question. Each question is analyzed and is associated with the results of interviews, findings and opinions of internal and external experts.
\end{abstract}

Keywords: Statistical Analysis, Satisfaction Analysis, Decision Making, Internal Analysis, Reorganization

\section{Özet}

Araştırmanın amacı, uzun zamandır Kipaş Grubunun üst yönetiminde çalışanların bakış açısı ile grubunun karşı karşıya kaldığı sorunları tespit etmektir. Kipaş Grubu'nun sorunların belirlenmesinde bilgi oluşturmaya yönelik olarak verileri toplanmak amacıyla anket teknikleri ve görüşmelerden yararlanılmıştır. Veriler frekans ve pasta grafikleri ve memnuniyet analizi kullanılarak analiz edildi ve görüş̧melerin bulgular ve gözlemleri ile birleştirildi. Kipaş Grubu bir holding kurmak amacıyla 2005 yılından beri yönetim yapısını, iç sorunlar ve dış şartlardan dolayı değiştirmeye karar verdi. Bu yüzden, örgüt yapısı hakkında bilgi toplamak amacıyla bazı anketler yaptık. Bu makalede, Kipaş Grubu'nun yeniden yapılanma projesinde yapılan anketlerin sonuçları bazı önemli bulguları ile birlikte sunulmaktadır. Grup hakkında 40 soru üst yönetimden 43 kişiye soruldu. Ayrıca, anket doldurulduktan sonra görüşmeler yapıldı. Bu soruların amacı, grubun çalışmaların nasıl yürüttüğgünü ve grubun güçlü ve zayıf tarafı ortaya çıkarmaktır. Grubu analiz ederken bu bulgulardan faydalanılmıştır. Her sorunun ortalama, standart sapma ve frekansı bulunarak grafikler ile sunuldu. Memnuniyet analizi her soru hakkındaki ortak görrüşü ögrenmek amacıyla yapıldi. Her soru analiz edildikten sonra mülakatlar, bulgular ve iç ve dış uzmanların görüşlerinin sonuçları ile ilişsilendirildi.

Anahtar Sözcükler: İstatistiksel Analiz, Memnuniyet Analizi, Karar Verme, İçsel Analiz, Yeniden Yapılandirma 


\section{INTRODUCTION}

Kipaş Holding's past dates back to establishment of Kahramanmaraş İplik Pamuk A.Ş in 1984. Through the reorganization of the group companies in 2005, Kipaş Holding is formalized by including numerous subsidiary companies. Kipaş Holding, a leading institution within its sector and renown due to her professionalism, its expertise and its high quality standards, is a precious member of Turkish Textile Industry whereby it transformed a mere cotton yarn manufacturing plant over years into a fully-integrated textile manufacturing giant. Kipaş Holding proves its insistence on high standards by maintaining quality certificates. Kipaş Holding, an institution that sets big goals for regional development and for our country, will continue to serve to our countries' future by leveraging the expertise gained throughout the 22 years (http:/ / www.kipas.com.tr/kurumsal.php?lang=EN\&pg=pro).

The second step of the reorganization project was completing the questionnaire. In this step, task force members determined who was best able to complete each section of questionnaire and takes responsibility for its completion. They discussed what supplementary materials might support the information provided in the questionnaire and take responsibility for obtaining them. To collect data and support decisions for the future of Kipaş, interviews and observations were simultaneously carried out. Findings from interviews and observations were integrated with questions of survey in this article. These findings were added to results from external and external environments to reorganize the group. We tried to make the project group from members of each firm and university to use the experience of workers and then combine with results of our findings and theoretical data. Findings from statistical analysis were so beneficial while creating strategies and organizing structure. We supported our decisions with its results.

\section{THEORETICAL BACKGROUND}

Statistical analysis is used to organize and analyze data in a logical and systematic way. Statistical methods rely on a best model to make accurate decisions. Statistical methods are developed to search a better decision making under uncertainties. Statistical thinking can help managers to make better strategies and apply the methods of statistics to their daily activities. In statistical model, data are converted to information. Later, they are accepted as facts. Improvements level on decision making is increased in this way until knowledge is gotten as shown Figure 1 below. The mean measure of central tendency and the standard deviation measure of data have a certain characteristic to help decision making (http:/ /home.ubalt.edu/ ntsbarsh/stat-data/surveys.htm\#rvsd; Kayaalp, 1997:33-42). There are two types' statistical methods which are description and inference methods to organize and to describe data. Descriptive statistics is used by both mathematical and graphical methods. Large amounts of data are produced concerning models. Thus, series of tables can be used to plot data. Depend on single or multiple dimensions, the type of tables can be chosen. There are modern visualization programs to show and analyze data. The basic types of visual charts such as pie charts and frequency graphs are used in our study (Richard Webber, http:/ /www.cs.usyd.edu.au / visual/valacon/pdfpers/EF06g_Space-fillingEconomic.pdf).

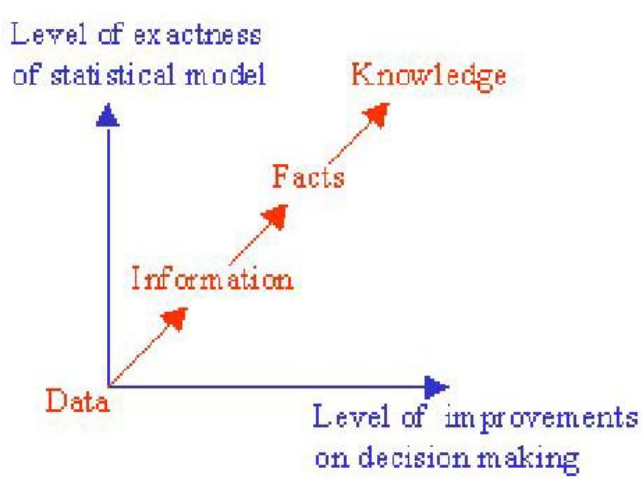

Figure 1: Creating Knowledge from Data Arsham, http://home.ubalt.edu/ntsbarsh/stat-data/topics.htm 
The choice of analyzing data depends on the kind of data involved. Data are categorized as discrete and numerical data (http://www.fao.org/Wairdocs/ILRI/x543 6E/x5436e05.htm). Discrete data can be plotted via bar charts. Bar chart is useful to see whether it is a continuous or not continuous data. (http://www.statcan.gc.ca/edu/ power - pouvoir / ch 9 / b a r g raphdiagrammeabarres/5214818-eng.htm). The pie chart is a clear tool to represent data. If it is intended to compare the slice with whole pie, it is useful. Pie charts also show frequency of events. Pie charts can be used as other techniques to see the relationships among variables. To show proportions as a whole, a pie chart can be used. A bar chart displays each data point as a horizontal bar, the length of which corresponds to the value (Spence, 2005: 353; William, 1985). A frequency histogram is used to determine central tendency and variation graphically. The most occurring values appear near the middle of the histogram with spreading out the variations in the bars (Tufte, 1997; Kevin, http:/ / www.referenceforbusiness.com/ency clopedia/Sel-Str/Statistical-Analysis-forManagement.html\#ixzz12Knm1g4N). In this study, descriptive estimates are used such as the totals, means, and proportions.

The main methods of collecting information are face-to-face interviewing, surveys, direct observations and internet. We used all these methods to get information about the group. Face-to-face interviews were carried out after surveys' forms were filled. With direct observations and internet, necessary information about the group was collected. Based on these observations, decisions were given (Arsham, Questionnaire Design and Surveys Sampling, http://home.ubalt.edu/ ntsbarsh/stat-data/surveys.htm\#rvsd). Size of the organization, structure of organization, products, industry of firm, service, clients, potential markets, stock history, company's main competitors, recent news items, trends, and problems of the firm should be known before starting the observations. Moreover past, current and potential growth of the firm and industry can be searched. A list of personal strengths and past accomplishments such as education, experiences, skills and accomplishments is prepared before interviews. Person specific key questions are prepared. During interviews, eye contact, body language and voice are noticed. Moreover, interviewer does not have to wait until the end to ask question. Questions can be asked mutually. All parties should talk clearly to understand each other (http:/ / www.studentaffairs.cmu.edu/career/students_alumni/successguides/pdf/i nterviews.pdf).

\section{STATISTICAL ANALYSIS OF KIPAŞ GROUP}

Statistical Analysis of Group has helped to collect data about the group for decision making. Each question is analyzed and findings related to this question are explained in details with suggestions. Frequency graphs, pie charts and satisfaction results are combined with interviews and observations' results.

\subsection{Frequency Graph}

Frequency graphs show the number of people who select a scale between 1 and 7 . The number of people selecting 1, 2 and 3 is preferred to be more. 4 are good for organization. But, 5, 6, and 7 are low scores especially 7. A frequency graph is prepared for each question to see whether workers are happy or unhappy about this question and to see their distribution. By looking at each question, the organization is analyzed. The question having very bad frequency is taken the attention. The aim is to find the workers attitude against to the firm.

\subsection{Pie Charts}

In pie charts, scale is divided into three main sections and the percent of people entering is found in each group to find whether workers are happy, little happy or unhappy, which is parallel with frequency graphs to see more clearly the results. When looked at seven scales, it is more difficult to analyze. 
Thus, with three sections, it is easier to see the picture of each question as shown in Table 1.

Table 1

Section with Their Scales

\begin{tabular}{|c|c|}
\hline Excellent & $1-2-3$ \\
\hline Good & 4 \\
\hline Poor & $5-6-7$ \\
\hline
\end{tabular}

\subsection{Satisfaction Analysis}

Satisfaction analysis is a simple way to analyze each question. With this analysis, all questions can be compared with each other. Strong and weak parts of the firm can be found. Questions with low score will take the attention of analyzers.

$$
\text { Satisfaction Level }=\frac{N_{1} x 100+N_{1} x 80+N_{1} x 65+N_{1} x 50+N_{1} x 30+N_{1} x 15+N_{1} x 0}{N_{1}+N_{2}+N_{3}+N_{4}+N_{5}+N_{6}+N_{7}}
$$

The number of each people select a scale is multiplied with its score and divided the sum of people to find a satisfaction score as shown in the equation 1 above. At scaling table, there are scales for each value, see Table 1 . As result, the higher score means that they are more satisfied with the situation. By looking this score, each question can be analyzed more easily. The mean of seven scales should be 50 .

Table 2

Scaling Table

\begin{tabular}{|c|c|}
\hline SCALING & \\
\hline So Wonderful(1) & 100 \\
\hline Wonderful(2) & 80 \\
\hline Very Good(3) & 65 \\
\hline Good(4) & 50 \\
\hline Not so good(5) & 30 \\
\hline $\operatorname{Bad}(6)$ & 15 \\
\hline Very bad(7) & 0 \\
\hline
\end{tabular}

3.4. Questionnaire Results of Top Management with Histograms, Frequency Graphs and Satisfaction Level Results.

Each question is analyzed subsequently. Later, these questions are compared in groups. With these data, we could see the beginning picture of the firm better. These findings were beneficial to support the suggestions. 


\section{How do you see your company among your competitors?}

1

$\begin{array}{llllll}2 & 3 & 4 & 5 & 6 & 7\end{array}$

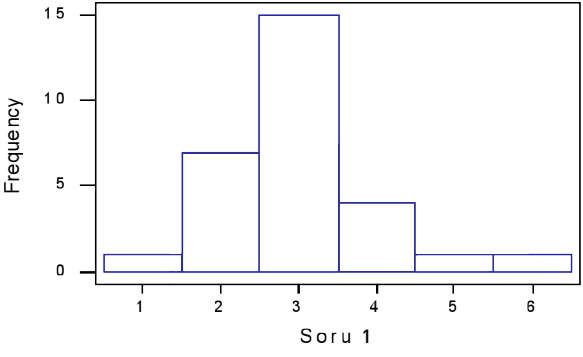

Figure 2 : Q.1's Frequency Graph

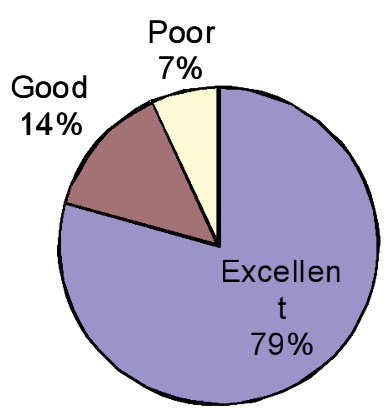

Figure 3 : Q.1's Pie Chart

\section{Satisfaction Level $=64.83$}

The number of people selecting 2 and 3 is higher than others. So, it can be said that the workers see their firm better than its competitors. $79 \%$ of people select good section and $14 \%$ of them select excellent section. Therefore, they see their organization better than their competitors, which is parallel with frequency graph.

Satisfaction level for this question is 64.83 which is between good and very good and it can be said that this result is good and they are happy about their company position. As you the percent of people select excellent section is high compared with 64.83, which means the number of people selecting 2 and 3 is higher than 1 since 100 is given for 1 (so wonderful). The group is thirtieth biggest firm in Turkey. Actually, there are better firms in textile sector. Sanko Holding is a main competitor of this group in its region.

\section{How do you see the financial position of your company?}

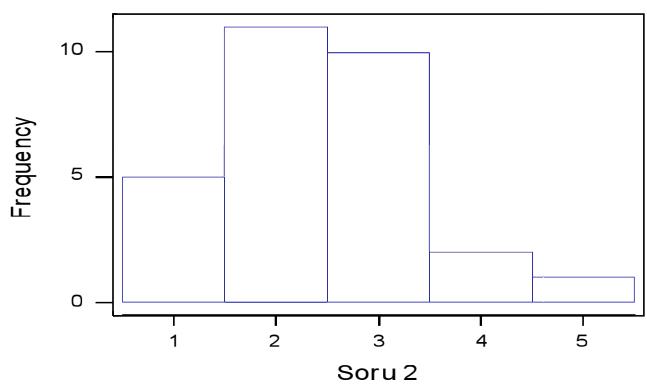

Figure $4:$ Q.2's Frequency Graph

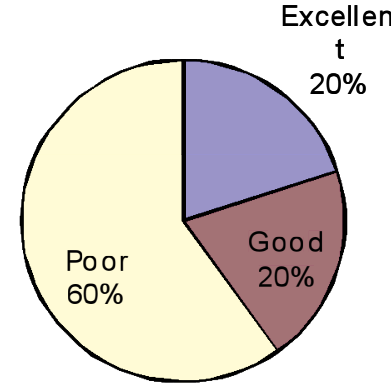

Figure 5 : Q.2's Pie Chart

\section{Satisfaction Level $=74.48$}

As seen from the figure, the financial position seems very good. The number of people selecting 1,2, and 3 is very high. $90 \%$ of people select excellent section, which means that their financial position is very high. 
74.48 satisfaction score is between so good and wonderful is a very good score for the firm. In this manner, other questions' satisfaction level can be analyzed. The firm had high cash for its further investments. They have been subsidized.

\section{What do you think about the organization of your company?}

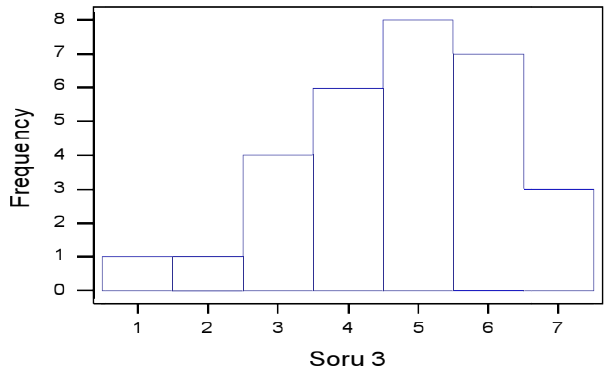

Figure 6 : Q.3's Frequency Graph

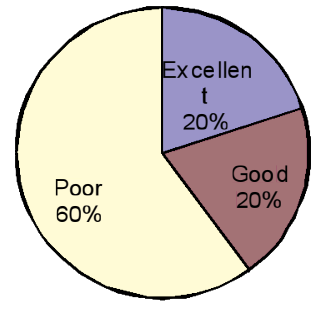

Figure 7 : Q.3's Pie Chart

\section{Satisfaction Level $=36.17$}

From both graphs, it is seen that the organization of group is poor. So based on this result, internal and external analysis, the organization structure of the group was reorganized to establish a holding. From interviews, it was noticed that the workers had many problems. They did not know well how to solve their problems. Dilemmas among stakeholders resulted in dissatisfaction of workers.

The organization of the company is not good as understand from three results, workers are unhappy about it.

\section{What do you think about the customers' potential?}

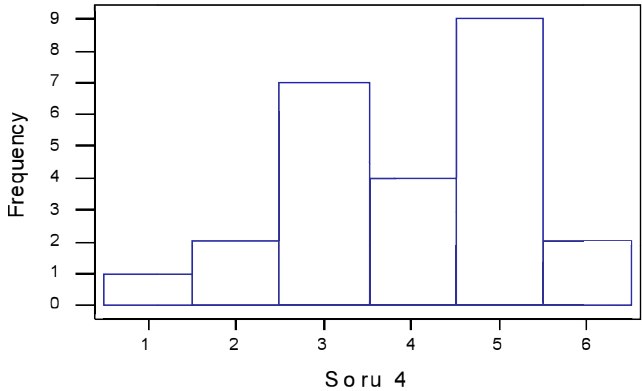

Figure 8 : Q.4's Frequency Graph

\section{Satisfaction Level $=47.96$}

Their customer potential is very low. They have decided to increase their costumers' potential by increasing their exportation. They have a sales branch in London but it is not enough to extend in other parts of Europe. 
5. What do you think about local ethics of your company?

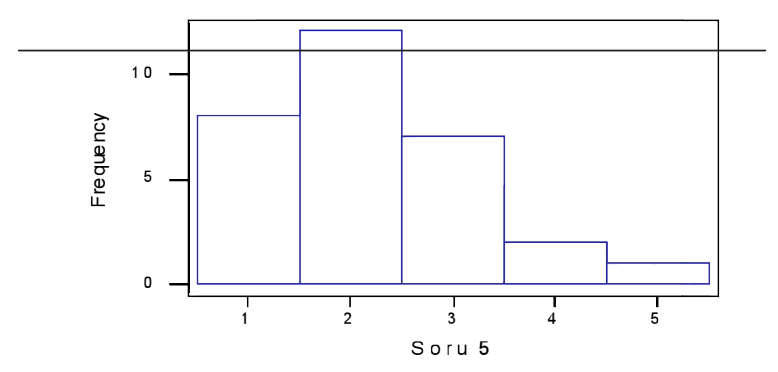

Figure 10 : Q.5's Frequency Graph

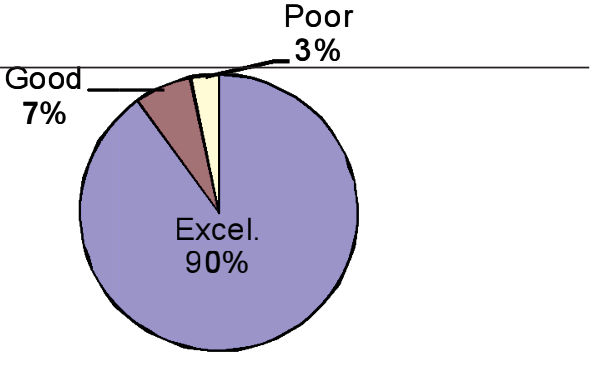

Figure 11 : Q.5's Pie Chart

\section{Satisfaction Level $=78.17$}

In three analyses, their local ethics are very good among workers. Even though in surveys, it is high, workers blamed each other during discussions sessions

\section{What do you think about your top managers' activities for your company?}

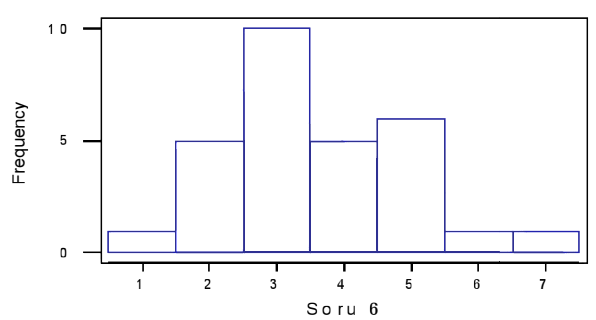

Figure 12 : Q.6's Frequency Graph

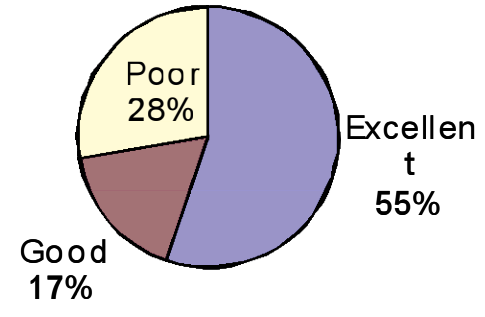

Figure 13 : Q.6's Pie Chart

\section{Satisfaction Level: 62.00}

It seems good score for top managers. However, conflicts among the owners are very high. Workers from different departments blamed each other about the problems of the firm.

\section{What do you think about your managers' education and knowledge?}

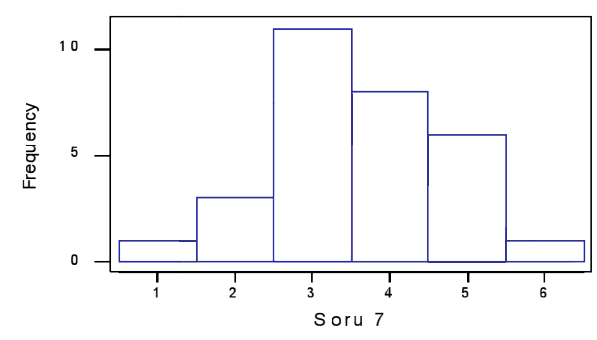

Figure 14 : Q.7's Frequency Graph

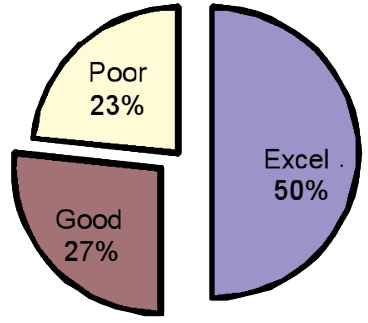

Figure 15 : Q.7's Pie Chart

Satisfaction Level: $\mathbf{5 5 . 0 0}$ 
It is not a high score. Managers of the firms are mainly from both families. Each family wants to get control over the group. They have employed relatives and they did not have enough qualifications for these positions. They have done what family members have said. This is one of the main problems of the group. Group needed professional managers for its operations. Some internal educations about strategic management were given to top management to find a common language with them. The details of project were explained to every person. It was expected from them to help the projects members. In each firm, some of them worked in collaboration.

\section{What do you think about your managers' approach when there is a problem?}

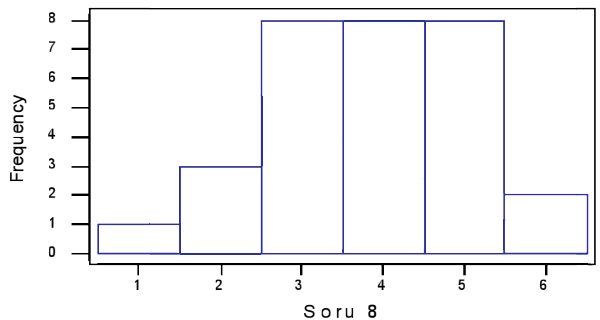

Figure 16 : Q.8's Frequency Graph

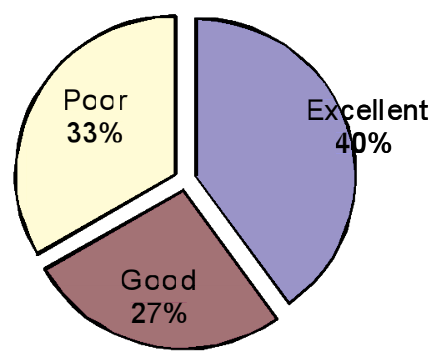

Figure 17 : Q.8's Pie Chart

Satisfaction Level $=\mathbf{5 1 . 0 0}$

It is a low score and workers were unhappy about their approaches. Actually, it is high score when it is compared with interviews. Workers explained all the times their bad situations about managers.

\section{What do you think about the relationships between customers and your managers?}

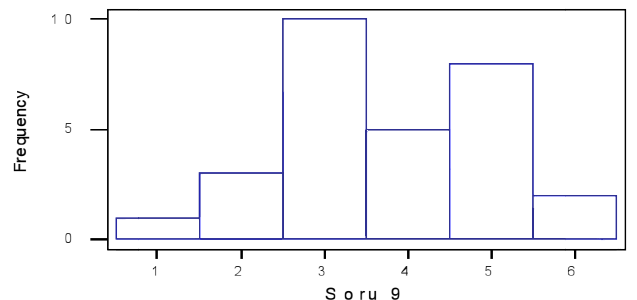

Figure 18 : Q.9's Frequency Graph

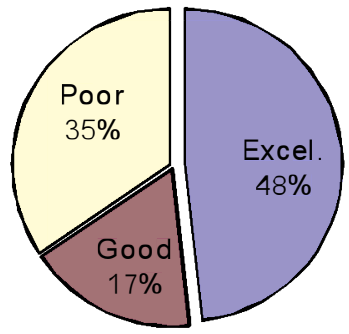

Figure 19 : Q.9's Pie Chart

\section{Satisfaction Level $=\mathbf{5 2 . 0 7}$}

Relationships between top managers and customers are not so high. Actually, managers were far from costumers and they do not want to get so much in contact with them. They get reports about costumers from their branches. 
10. What do you think about the relationships between workers and your managers?

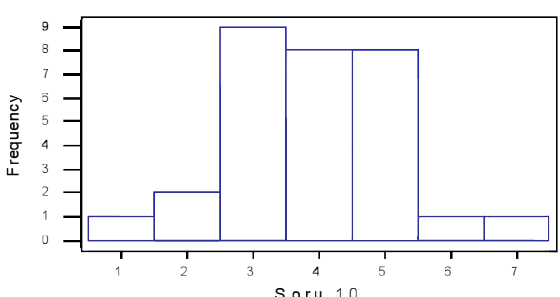

Figure 20 : Q.10's Frequency Graph

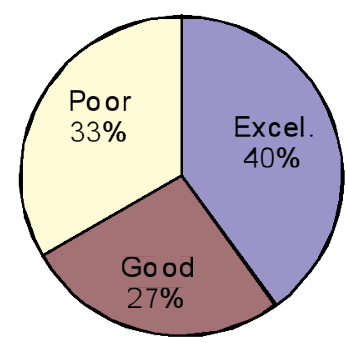

Figure 21 : Q.10's Pie Chart

\section{Satisfaction Level $=\mathbf{5 0 . 0 0}$}

The relationship between workers and managers is not very good. From interviews, they showed that they could not tell their opinion directly. Managers were angry when workers said their opinions about the firm.

\section{What do you think about the structure of your organization?}

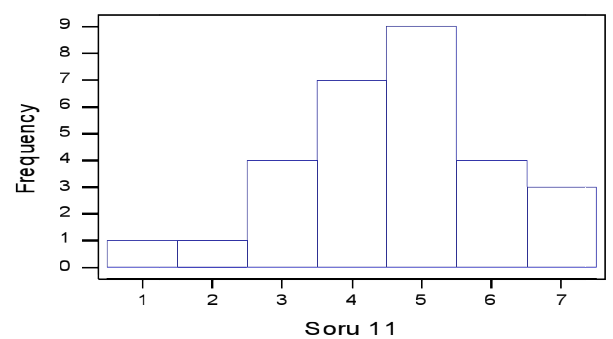

Figure 22 : Q.11's Frequency Graph

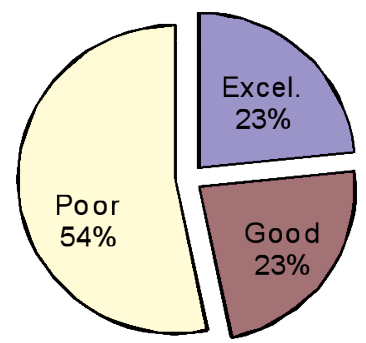

Figure 23 : Q.11's Pie Chart

\section{Satisfaction Level $=40.00$}

Organization's structure is very bad since the firms are far each other and also the coordination among firms is not good. Moreover, they want to change its management structure to holding one. All firs are consolidated under this structure.

12. What do you think that your company gives enough attention for the education?

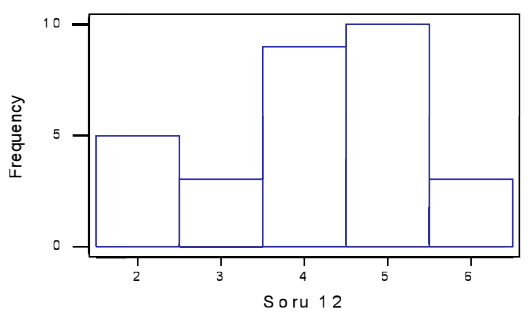

Figure 24 : Q.12's Frequency Graph

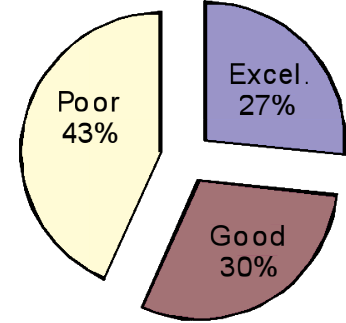

Figure 25 : Q.12's Pie Chart

Satisfaction Level $=46.33$ 
They were not any human resource and education activities. Workers attend fairs but they want to get education about their occupations, working field and languages which were not supported by the firms. There were not any career and performance measurement activities.

\section{What do you think about your company approach for salary policy?}

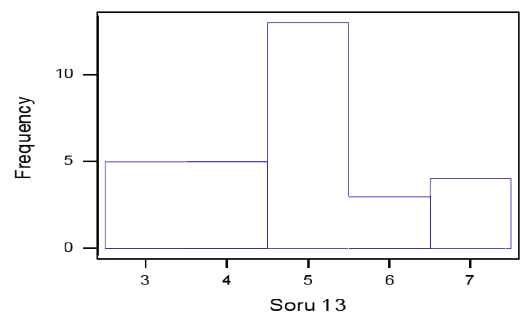

Figure 26 : Q.13's Frequency Graph

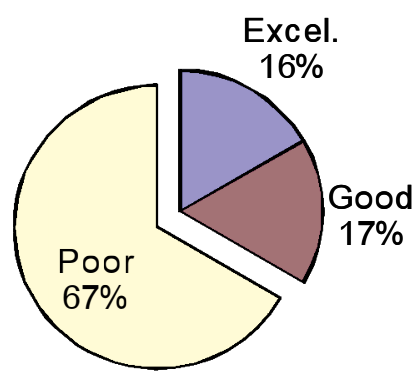

Figure 27 : Q.13's Pie Chart

\section{Satisfaction Level $=33.67$}

Salary policy of the firm was bad as you see from statistical results and also from interview, which was told it directly. The salaries of new engineers were not high when it was compared. Mangers of one of the firm of group did not employ two qualified engineers from a top university of Turkey since they wanted high salary. Their salary policy was to employ middle qualified workers with low costs.

\section{What do you think about sales activity of your company?}

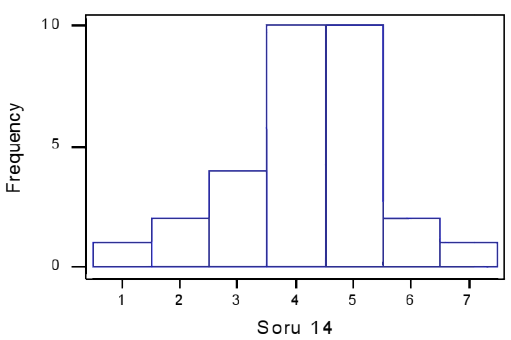

Figure 28 : Q.14's Frequency Graph

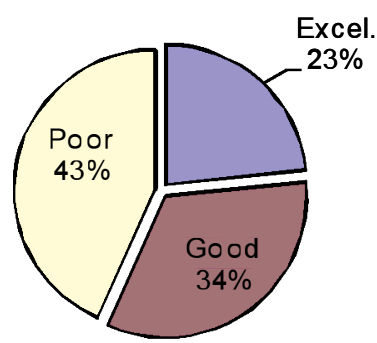

Figure 29 : Q.14's Pie Chart

\section{Satisfaction Level $=45.00$}

Their sales activities seem good from results. They want to increase their sales activities and have struggled for it to extend in EU and USA. Even in domestic market, they had lost some share of their market share to international firms. The competition is high and their market is in danger. They have to change their activities and workers emphasized on it. 
15. What do you think about relationships between your company and suppliers?

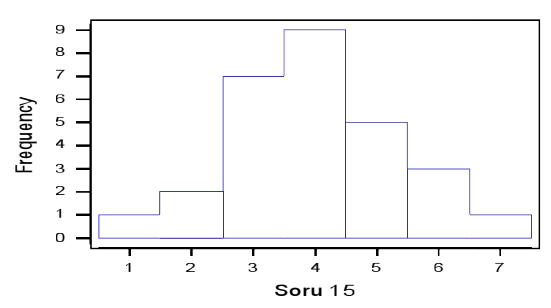

Figure 30 : Q.15's Frequency Graph

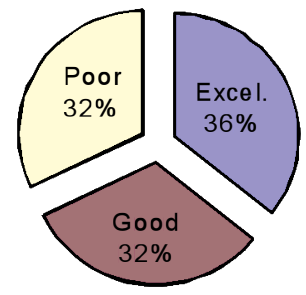

Figure 31 : Q.15's Pie Chart

Satisfaction Level $=48.57$

Relationship between suppliers and company seems good. 36\% of workers said that they have excellent relationship with suppliers. Each firm is also a supplier of another one. Family members are managers of these firms. They have employed many relatives and they were expected to give high score.

16. What do you think about politics relationships of your company?

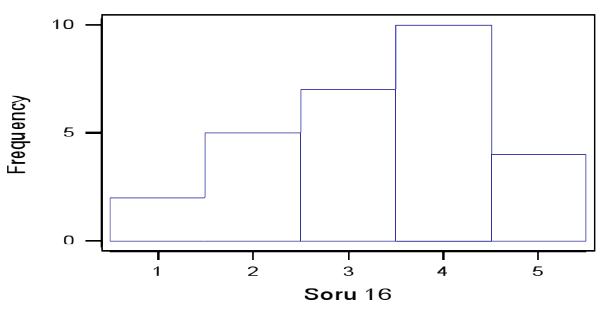

Figure 32 : Q.16's Frequency Graph

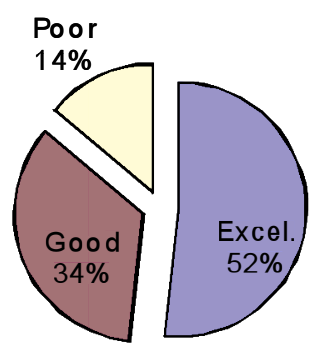

Figure 33 : Q.16's Pie Chart

\section{Satisfaction Level $=60.55$}

The politics of the company are high with $52 \%$. Actually, some workers did not have clear opinion about this question. We asked to learn a common idea about the politics of the firm related to organization and management. They have mainly understood as political relationship of the firm with governments. The firm has a good relationship with governments and got many supports from them for regional development (South Anatolia Project). 
17. What do you think about strategies of your company?

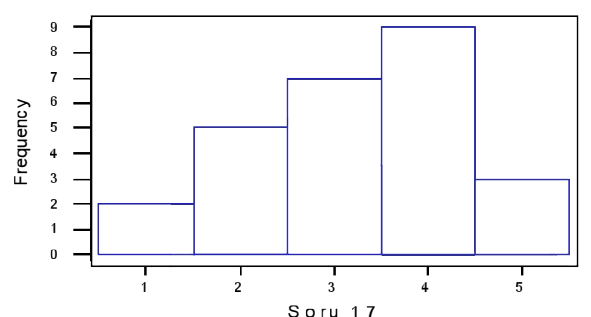

Figure 34 : Q.17's Frequency Graph

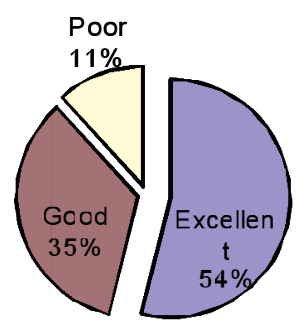

Figure 35 : Q.17's Pie Chart

\section{Satisfaction Level $=61.55$}

$54 \%$ of workers gave excellent point and this is a good score for the group. Group has made many investments in last 26 years with right strategies. From a small firm, they are now a holding.

18. What do you think about relationships between competitors and your company?

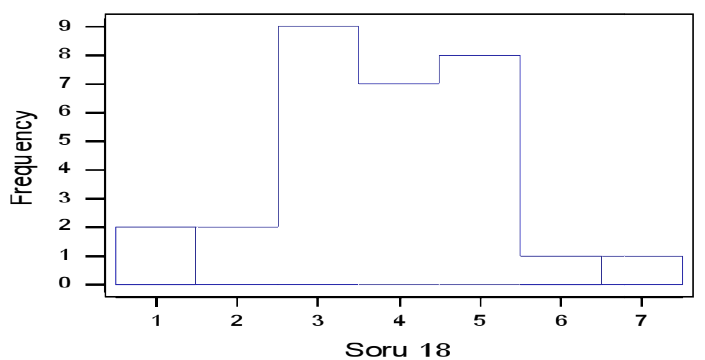

Figure 36 : Q.18's Frequency Graph

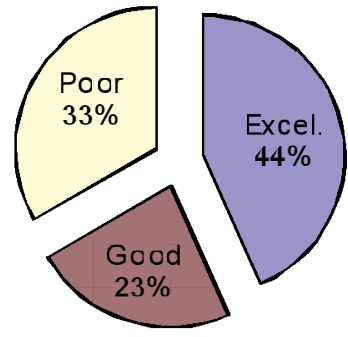

Figure 37 : Q.18's Pie Chart

\section{Satisfaction Level $=51.67$}

Relationships between competitors and company seem low. It is not expected that competitors have good relationships. However, some competitors can work in coordination to control the market. In Turkish Textile Sector, there are many competitors.

19. What do you think about relationships among the workers?

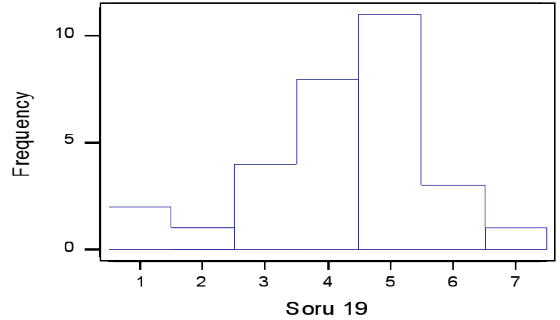

Figure 38 : Q.19's Frequency Graph
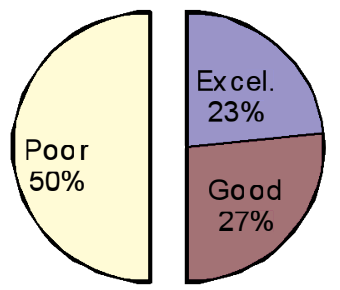

Figure 39 : Q.19's Pie Chart

Satisfaction Level $=43.83$ 
Relationships among workers is low with $50 \%$ poor and in interviews, they blamed each other about the problem of firms.

20. What do you think about performance measurement system of your company?

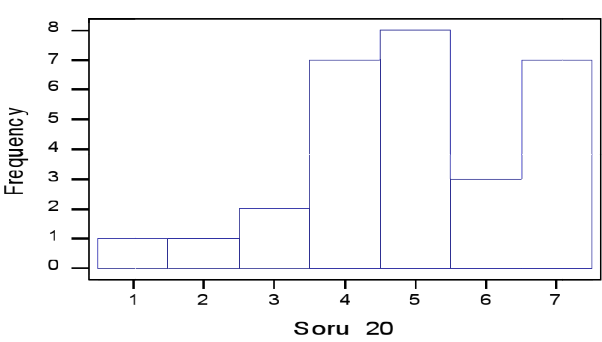

Figure 40 : Q.20's Frequency Graph

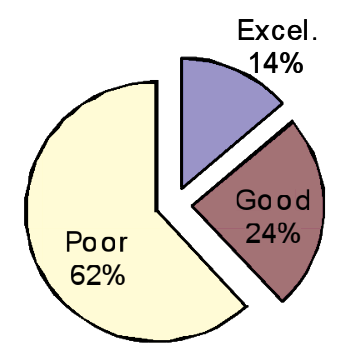

Figure 41 : Q.20's Pie Chart

\section{Satisfaction Level $=32.59$}

There was not any performance measurement system in the firm. $62 \%$ of workers find the performance measurement system poor. Mangers evaluated workers roughly without any statistical data. Daily coming to work and doing their jobs properly are some points using to measure the performances.

21. What do you think about production technologies of your company?

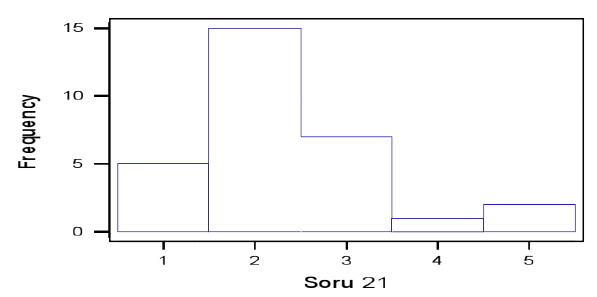

Figure 42 : Q.20's Frequency Graph

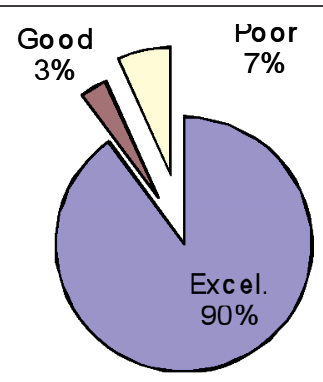

Figure 43 : Q.20's Pie Chart

\section{Satisfaction Level $=75.50$}

They have very good production technology with $90 \%$ survey result. They have invested in last textile technology for years. However, in other areas, their technology is not so good. Especially, they do not have a high communication technology among firms. 
22. What do you think about communication among the workers?

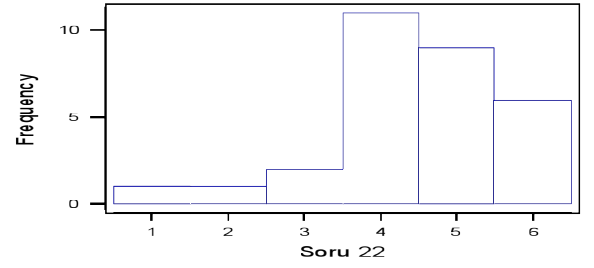

Figure $44:$ Q.22's Frequency Graph

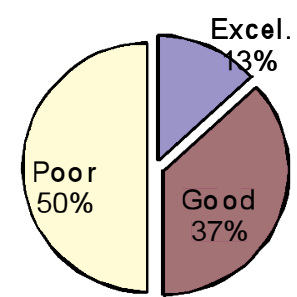

Figure 45 : Q.22's Pie Chart

\section{Satisfaction Level $=40.67$}

They have serious problem about communication. During brainstorming section, they blamed each other as they did in interviews. It is also clear from our analysis. Only $17 \%$ select excellent section and satisfaction score is only 40.67. It appears in frequency graph more clearly.

23. What do you think about information technologies of your company?

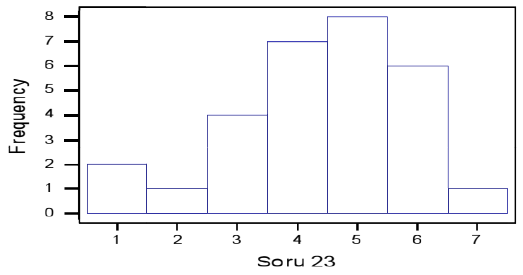

Figure 46 : Q.23's Frequency Graph

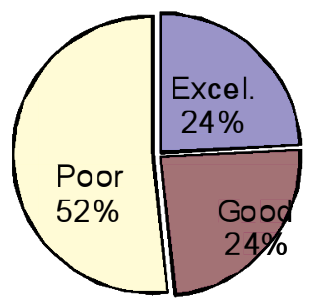

Figure $47: Q .23$ 's Pie Chart

\section{Satisfaction Level $=42.07$}

They are not happy about their information technologies. They have bought a program to combine the whole information of all group firms, but they have had some problems during the implementation phase. In interviews, it was understood that they do not have qualified engineers to implement and control it. They gave the implementation task to some workers from the firm, but they have not completely adapted it.

24. What do you think about your company's investment?

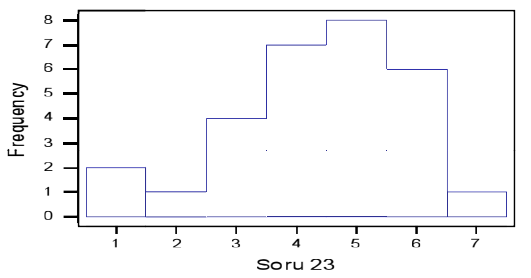

Figure 48 : Q.24's Frequency Graph

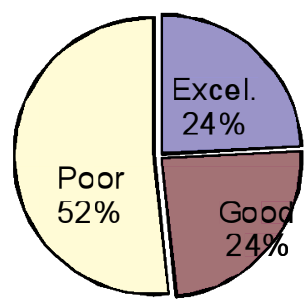

Figure 49 : Q.24's Pie Chart

Satisfaction Level $=76.21$ 
Their most powerful side is their investments. They become one of most important firm in Turkey in 26 years. 93\% excellent survey result is an admiring result. To become thirstiest biggest firm in Turkey is a challenge and they have done it.

25. What do you think about international fame of your company?

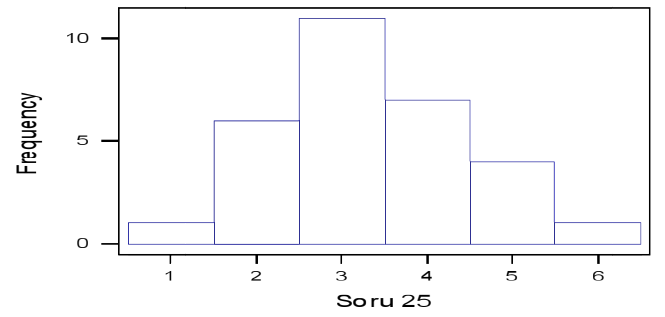

Figure 50 : Q.25's Frequency Graph

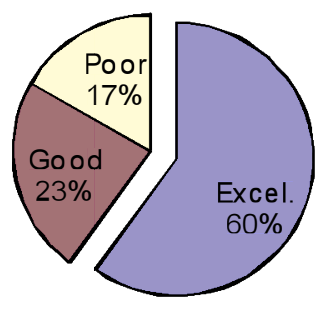

Figure 51 : Q.25's Pie Chart

\section{Satisfaction Level $=\mathbf{5 9 . 3 3}$}

They sell their products mainly to abroad. They made $\$ 55$ million exportation in 2004. They have a good reputation, but they have not had their own brand. They have sold mainly their products to big firms and gross retailers in Europe. In turkey, they are really famous firm and the only biggest firm in Kahramanmaraş a city of Turkey.

\section{What do you think about workers' education and knowledge?}

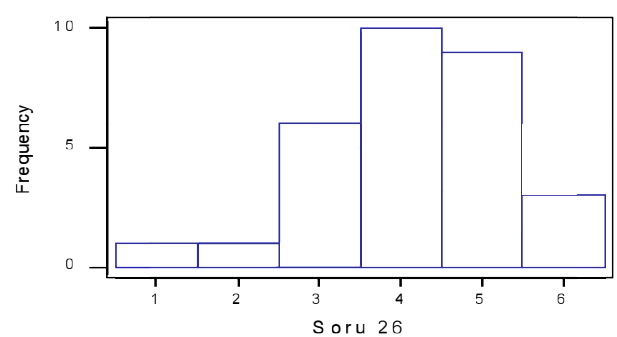

Figure 52 : Q.26's Frequency Graph

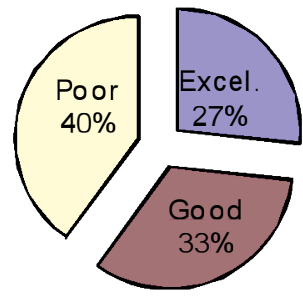

Figure 53 : Q.26's Pie Chart

\section{Satisfaction Level $=46.17$}

As I mentioned, they have not had any education activities. So, the result is low, which is seen more clearly from figures. 
27. What do you think about your company's approach for new markets and products?

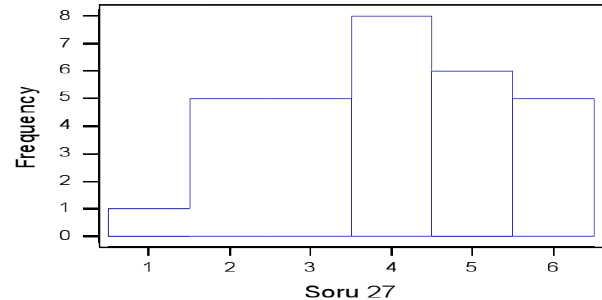

Figure 54 : Q.27's Frequency Graph

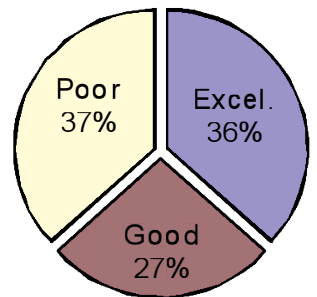

Figure 55 : Q.27's Pie Chart

\section{Satisfaction Level $=49.33$}

They want to enter new markets with new products, but until now, they are not so successful at that. They have used their existing products to get share in uncovered markets for them. They have not had well developed Research and Development department. They should make some searches about local markets in European Union.

28. What do you think about marketing activities of your company?

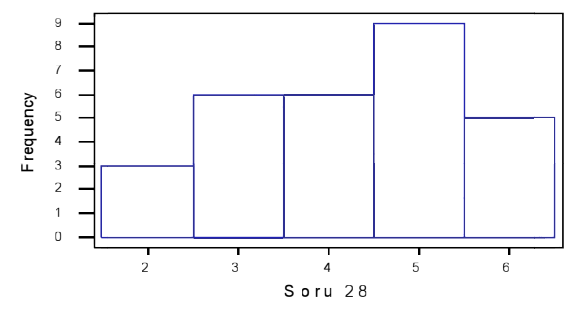

Figure 56 : Q.28's Frequency Graph

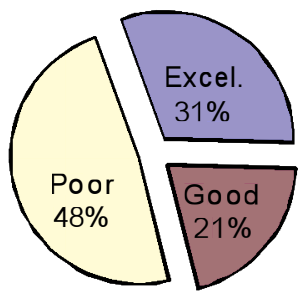

Figure 57 : Q.28's Pie Chart

\section{Satisfaction Level $=43.97$}

Their marketing score is not so high. They have done marketing activities of all firms from a center. They did not have good communication of marketing activities with other firms. It is expected to increase marketing activities to increase sales.

29. What do you think about authority and responsibility balance in the company?

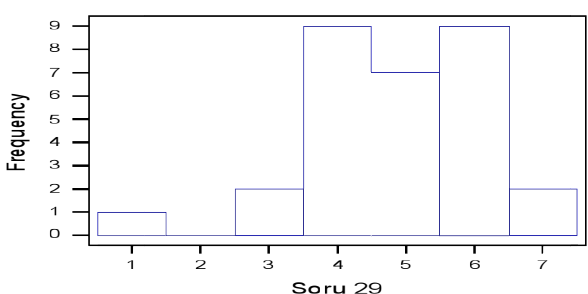

Figure 58 : Q.29's Frequency Graph

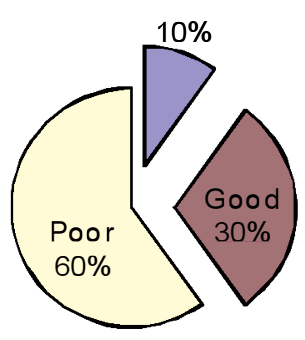

Figure 59 : Q.29's Pie Chart

Satisfaction Level $=34.17$ 
They think that their duties and responsibilities are balanced unequally with low 34.17 score. This is one of the most critical parts of survey. Workers did know with whom about the problems talk. There are many people who wanted to do the same things. It was decided to prepare the organization handbook to overcome this problem. They would know duties, responsibilities, and hierarchy. They would know against whom they are responsible. Moreover, it is clearer to whom reporting.

30. What do you think about planning and logistic activities of your company?

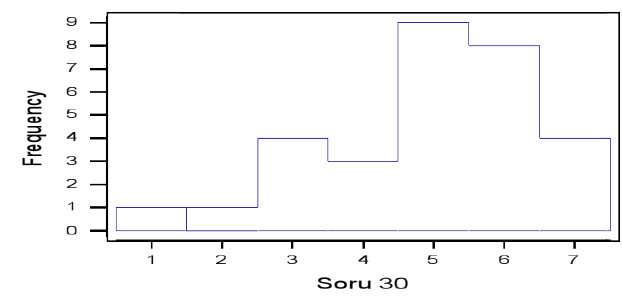

Figure 60 : Q.30's Frequency Graph

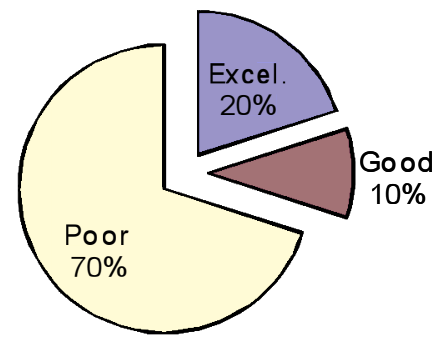

Figure 61 : Q.30's Pie Chart

\section{Satisfaction Level $=32.67$}

They do not have any logistics and planning activities in the organization. $70 \%$ of workers selected poor option(s). New logistic and planning departments were established in new organization. These two departments should be considered together. With logistics activities, you can make your plans more clearly. Textile production requires huge amount of place for storage.

\section{What do you think about creativity activities of your company?}

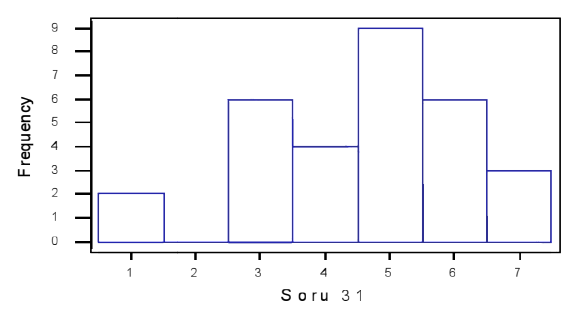

Figure 62 : Q.31's Frequency Graph

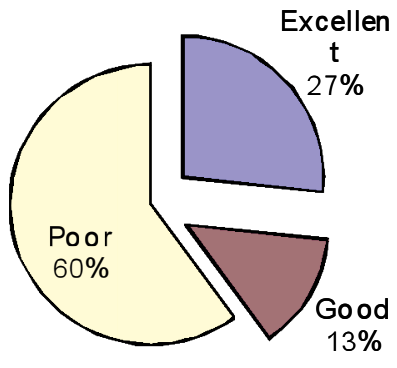

Figure 63 : Q.31's Pie Chart

\section{Satisfaction Level $=38.33$}

There are not any creativity activities in the firm. From satisfaction level, you can see it more clearly. They had not done any activity about that. 
32. What do you think about company approach to the complaints of customers?

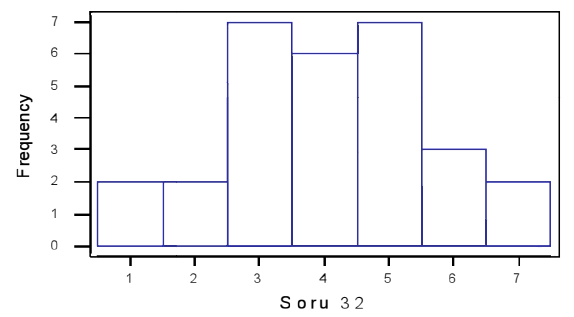

Figure 64 : Q.32's Frequency Graph

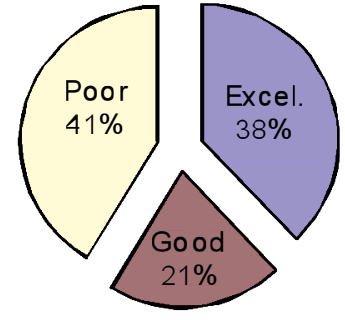

Figure 65 : Q.32's Pie Chart

Satisfaction Level $=47.27$

Actually 47, 27 is low score. In new strict competition area, costumers are the most valuable part of the firms. Now, in your domestic market, you have to compete with international and national competitors. Customers have more alternatives for the same product. One can ask himself why they should buy my product. Unsatisfied costumers will not buy the same product gain. Costumers' complaints should less $1 \%$ percent.

33. What do you think about accounting and financial systems of your company?

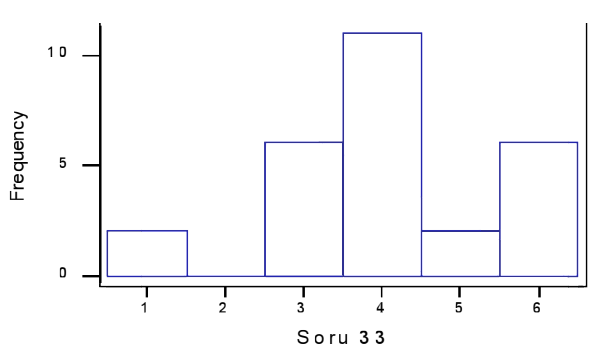

Figure 66 : Q.33's Frequency Graph

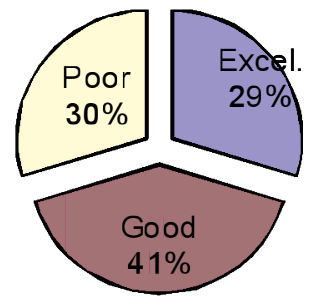

Figure 67 : Q.34's Pie Chart

\section{Satisfaction Level: 47.78}

They see their finical system well. Financial system is controlled by the managers of the company. They are mainly unhappy about it. Without the permission of mangers, they could not do anything. They use a standard accounting and financial system in their company.29\% survey result is so low for this section. They aimed to consolidate all firms of accounting and financial systems in new organization structure. 
34. What do you think about engineering approach of your?

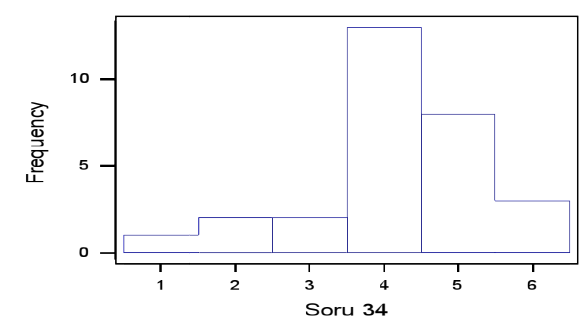

Figure 68 : Q.34's Frequency Graph

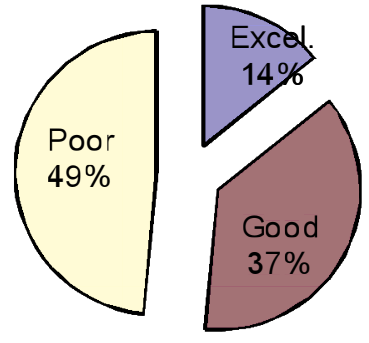

Figure 69 : Q.35's Pie Chart

\section{Satisfaction Level $=39.14$}

Engineering approach is so low. Almost $49 \%$ of workers stated that it is poor. It is clear from satisfaction score too.

35. What do you think about your company power against the new competitors?

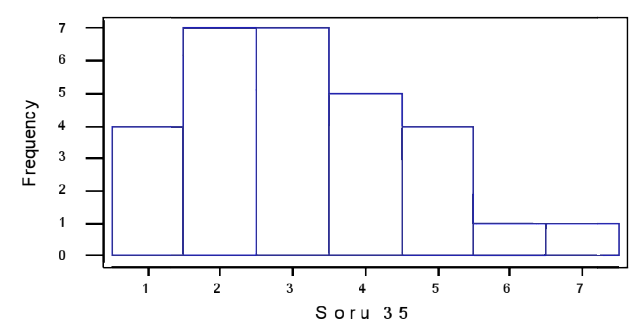

Figure 70: Q.35's Frequency Graph

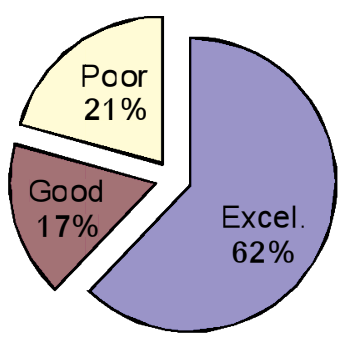

Figure 71: Q.35's Pie Chart

Satisfaction Level $=62.07$

Their power against new competitors is very good. They have mainly selected 1, 2, 3, and 4 in scale. 62.07 satisfaction score is a good result when compared with other questions. They have very financial power when compared with some good competitors. Their biggest competitor is Sanko Holding in their region and when compared with it, it is stay behind of it.

36. What do you think about the efficiency of the processes?

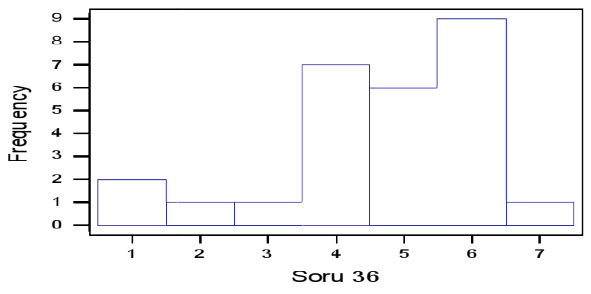

Figure 72: Q.36's Frequency Graph

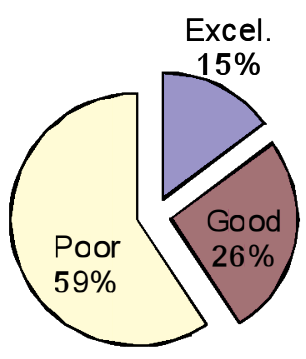

Figure 73: Q.36's Pie Chart

Satisfaction Level $=37.41$ 
For Kipaş, efficiency is a big problem as it is in Turkish textile. Its score is very bad. In textile, they use mainly human source and long work hours result in inefficiency. They had not done project related to increase the efficiency of the firm.

37. What do you think about expansion of your company in the other countries?

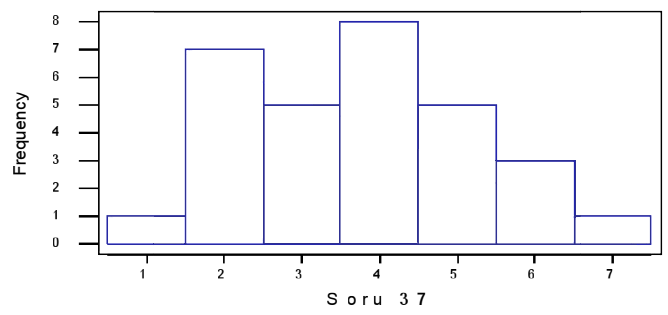

Figure 74: Q.37's Frequency Graph

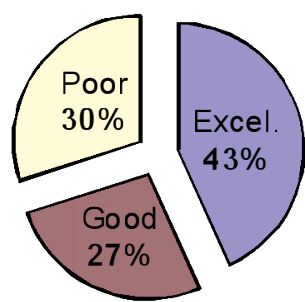

Figure 75: Q.37's Pie Chart

\section{Satisfaction Level $=52.67$}

In frequency graph and pie chart, it is clearer. They should expand in international markets. They have a good market share in Turkey, but the conditions are changing and they have to get new markets. Their internal market is in danger and they want to expand. The best way to do that is to find new markets.

38. What do you think about the payments of your company?

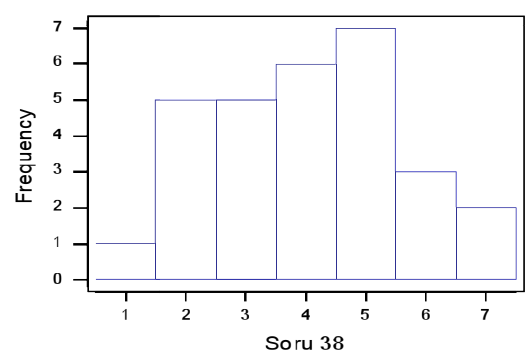

Figure 76: Q.38's Frequency Graph

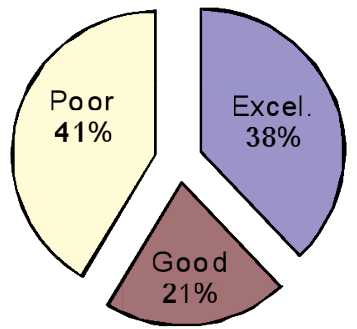

Figure 77: Q.38's Pie Chart

\section{Satisfaction Level $=47.59$}

$41 \%$ of workers from top management find it poor. Actually, they pay the standard payments and it is not so high. Their first selection criteria were to find workers not wanting high salary. 
39. What do you think about communication between Kahramanmaras and Istanbul?

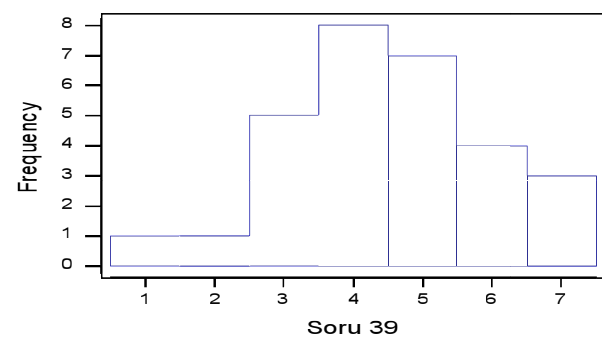

Figure 78: Q.39's Frequency Graph

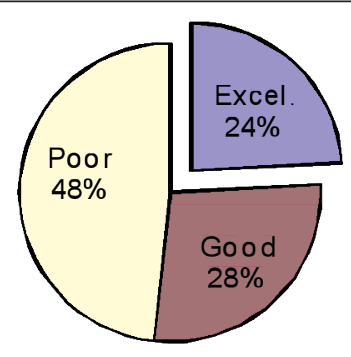

Figure 78: Q.39's Pie Chart

\section{Satisfaction Level $=40.52$}

The communication about Kahramanmaras and Istanbul is not very good. The main problem is that they are far from each other, but they are supplier of each other too. They did not have good information technology to see the operation of each other online. Again, they blamed each other about problems related communication problems.

\section{Where do you want to see your company after 5 years?}

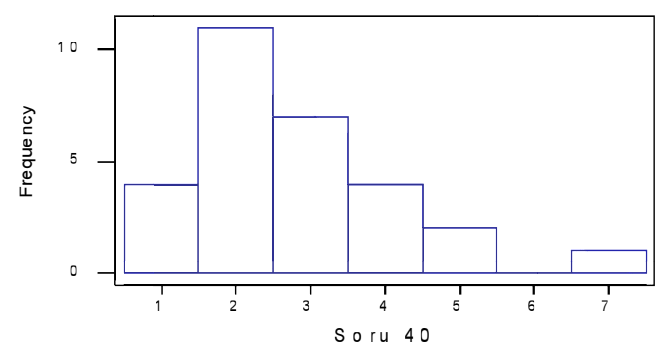

Figure 80: Q.40's Frequency Graph

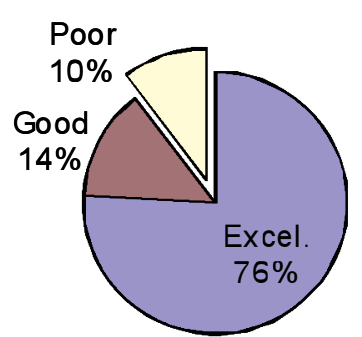

Figure 81: Q.40's Pie Chart

\section{Satisfaction Level $=68.79$}

They are very optimistic about future. 68.79 satisfaction level is a score for the firm. We have started this project in 2005 and now, it is 2010. The group is a holding and has grown even in crisis of between 2008 and 2010 period.

\section{CONCLUSION}

To analyze the groups, statistical analysis of group firms was carried out with surveys, interviews and internal analysis. With help of statistical analysis, the weak and strong sides of group were found. In next stages of satisfaction analysis, the mean of all questions can found and compared with each other. Moreover, questions can be grouped according to their field such sales or communication. The suggestions were grounded from the results of questions. The yields of vertical growth are uncontroversial and Kipaş is a good instance of this. Kipaş has all steps of supply chain of textile from cotton apparel. However, just last step of general supply chain is neglected by Kipas that is retailing. Kipaş must concentrate on last and most value added part of chain. Creation of own brand is the most important step in this essence. In the light of the developments in EU journey of Turkey, as a strategy, Kipaş can start its retailing ac- 
tivities in Western Europe, more value-added markets rather than domestic market. The company has the knowledge, culture and values to implement the aforementioned strategies and proposed organizing structure.

The textile apparel sector is in a transition era and January 1, 2005 was a cornerstone for sector. The 40 years temporarily protection, began with GATT agreement, of developed countries' textile apparel sector has been terminated. After failing the attempts against China such as Istanbul Declaration, to extend the deadline for implementation of the final integration stage from January 1, 2005 to December 31, 2007, significant player of the market including Turkey began to focus on non-tariff quotas or investigation of China due to unfair advantage as a result of government policies (currency manipulation, state subsidies...) Noticing the reactions and rapid increasing portion of China's in the market, the developed countries have been taking precautions and China respond to reactions with a little increase in tax of these sectors. Despite these recent developments, it is impossible to turn to conditions before 2005 and the revolution in the sector initiated with new rules. A global statistical analysis was carried out to see the firms of Turkey in global market. Moreover, Kipaş Group was analyzed in this situation. 


\section{References}

About Kipaş (2010), http://www.kipas.com.tr/kurumsal.php?lang=EN\&pg=pro

Arsham, Hossein (2010), http:/ / home.ubalt.edu/ntsbarsh/stat-data/surveys.htm\#rvsd

Kayaalp, Mehmet (1997), Ted Pedersen and Rebecca Bruce , A Statistical Decision Making Method: A Case Study on Prepositional Phrase Attachment. In T.M. Ellison (ed.) CoNLL97: Computational Natural Language Learning, ACL, p. 33-42.

Webber, Herbert and Jiang (2010), Space-filling Techniques in Visualizing Output from Computer Based Economic Models, http://www.cs.usyd.edu.au/ visual/valacon/pdf/papers/CEF06g_Space-fillingEconomic.pdf.

Arsham, Hossein (2010), Topics in Statistical Data Analysis, http:/ /home.ubalt.edu/ntsbarsh/stat-data/topics.htm

http:/ /www.fao.org/Wairdocs/ILRI/x5436E/x5436e05.htm.

http:/ / www.statcan.gc.ca/edu/power-pouvoir/ch9/bargraph-diagrammeabarres/5214818eng.htm.

William, Cleveland (1985), The Elements of Graphing Data. Pacific Grove, CA: Wadsworth \& Advanced Book Program.

Spence, Ian (2005), No Humble Pie: The Origins and Usage of a Statistical Chart, Journal of Educational and Behavioral Statistics, Vol. 30, No. 4, pp. 353.

Tufte, E.R. (1997), Visual Explanations: Images and Quantities, Evidence and Narrative, 2nd edition. Graphics Press, Cheshire, Conn.

http:/ / www.referenceforbusiness.com/encyclopedia/Sel-Str/Statistical-Analysis-for- Management.html

Chromy, Abeyasekera (2010), Statistical analysis of survey data, Household Surveys in Developing and Transition Countries: Design, Implementation and Analysis, p.1.

http:/ /home.ubalt.edu/ntsbarsh/stat-data/surveys.htm\#rvsd

http://www.studentaffairs.cmu.edu/career/students_alumni/successguides/pdf/interviews .$p d f$

http:/ /www.hope.edu/student/career/resources/PreparingInterview.pdf

Creative Careers is part of Student Services at University of the Arts London (2007), creative careers preparing for interview, p.4, http://www.arts.ac.uk/docs/preparingforinterview.pdf 
